\title{
朝鮮產岩石及び鑛物のラヂウム含量（其二） 江原道高城郡外金剛面金剛鑛山産諸鑛物のラチウム含量
}

(昭和十七年十月六日受領)

㧝。藤信房

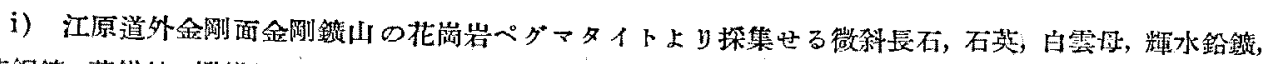

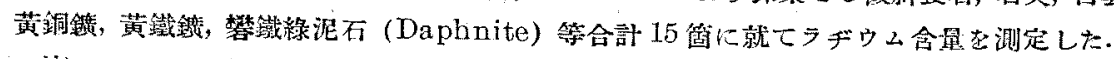

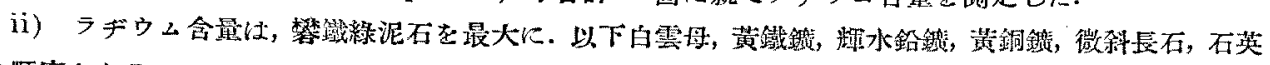
の順店となる。

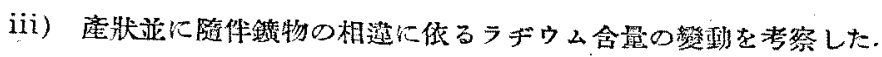

iv）ラヂウム合量を他地方虐に就ての湘定值と比校した.

笋者は先に咸鏡北道鶴城郡鶴南面達利洞産諸鍍物のラヂウム含量な测定報告したが，今回は江原道

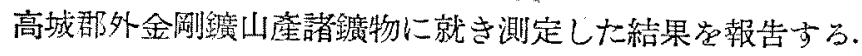

\section{賽 驗 目 的}

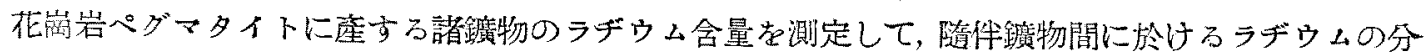
配を考究し，特に硫化鑛物のラデウム含量を知りたい.

\section{實 驗 試 料}

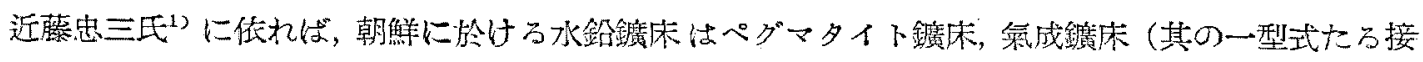

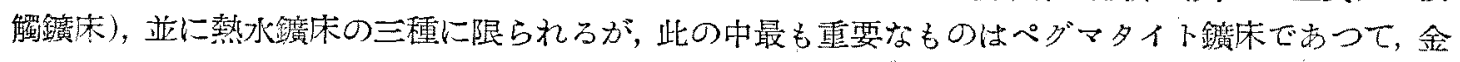
剛鑪山は其の代表的の者の一である. 而して本邦內地及び滿洲には此の種に屬する者の少いのは注目 に值する亭實である。

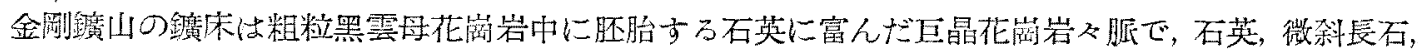

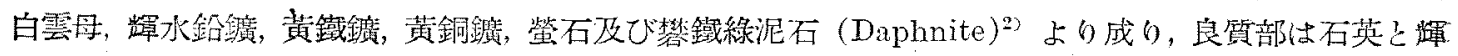

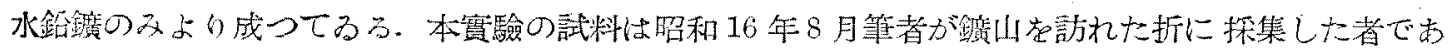
る.

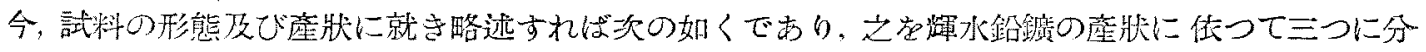
類京方.

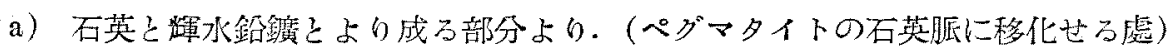

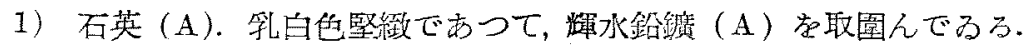

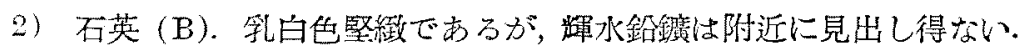

3）石英 (C). 白色. 晶洞に産する良結晶.

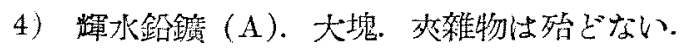

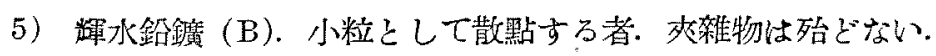

* 其一：本誌, 64(昭和 18), 1 .

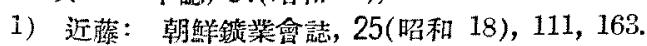

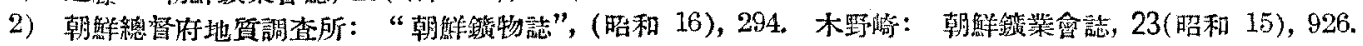




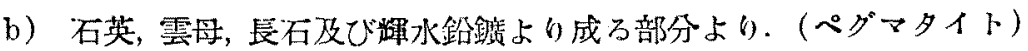

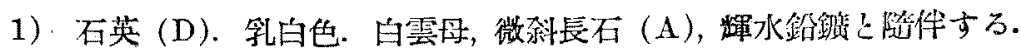

2）白雲母. 綠色の小片在なして石英と極めて密に存古る.

3）微科長石 (A). 肉白色で結晶が明かでない，石英 (D) と随件す万.

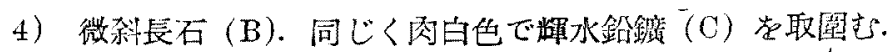

5) 輝水銿擴 (C). 中粒. 微科長石 (B) 中に晶出与万.

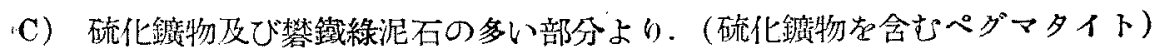

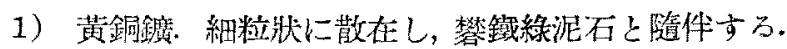

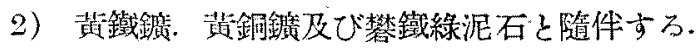

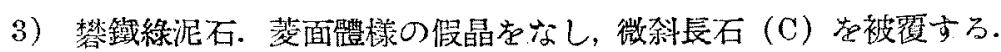

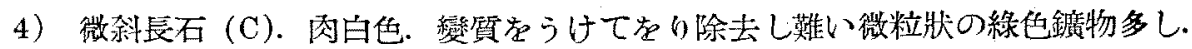

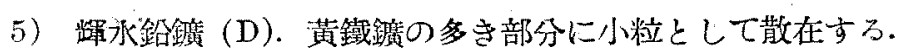

此の外に䖝石，磁硫鐵鑑が散點してるるが，試料僅少の篇，實驗には供しないの.

\section{測 定 方 法}

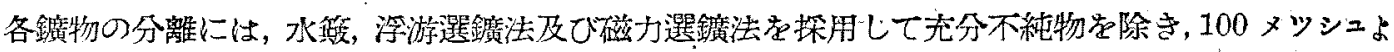

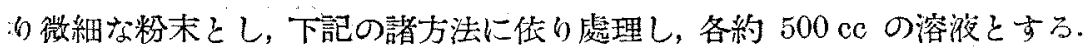

1) 石英: 微科長石. 白雲母. 攀鐵綠泥石.

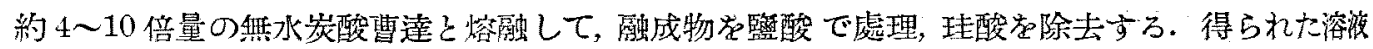
に硝酸 5 cc 在加へろ.

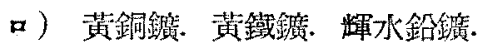

王水を以て分解し蒸發乾涸後，監酸にて處理し不溶殘㳯心滤別す万. 不溶殘㳯心弗化水素々硝酸

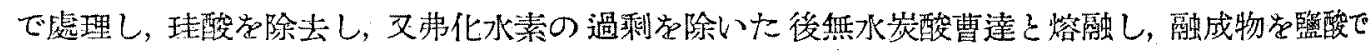

第1䒾 鋌物のラデウム含量

\begin{tabular}{|c|c|c|c|c|c|c|c|c|}
\hline 標本香虎 & & 鉒 & 物 & 名 & 随 作 䥄 物 & 比 重 & $\begin{array}{c}\text { 供試 } \\
(\mathrm{g}) \text { 䨢 }\end{array}$ & 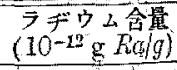 \\
\hline M 23 & 石 & & & 资 (A) & 辉 水鉛 鋃 (A) & 2.64 & 21.081 & 0.10 \\
\hline 11 21 & 石 & & & 英 (B) & & 2.63 & 20.657 & 0.12 \\
\hline NI 20 & 石 & & & 资 (C) & & 2.64 & 23.863 & $0.09:$ \\
\hline M 15 & 敞 & 水 & 鉿 & 䥊 (A) & 宾 (A) & 4.83 & 9.980 & 0.94 \\
\hline M 17 & 粞 & 水 & 跺 & 籍 (B) & 石 笑 & 4.83 & 10.247 & 0.87 \\
\hline$M 22$ & 石 & & & 些 (D) & 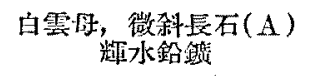 & 2.64 & 20.126 & 0.18 \\
\hline M 19 & 白 & & 雲 & 母 & 石 像 & 2.98 & 8.141 & 2.97 \\
\hline$M 24$ & 微 & 斜 & 長 & 石 (A) & 石 英 (D) & 2.53 & 10.065 & 0.72 \\
\hline M 25 & 微 & 䣄 & 長 & 石 (B) & 輝 水鉛鑑 (C) & 2.57 & 10.249 & 0.67 \\
\hline$M 16 i$ & 齿面 & 水 & 积 & 锤 (C) & 微 科 唇 石 (B) & 4.84 & 10.575 & 1.04 \\
\hline M 27 & 落 & & 銅 & 鈸 & 勢 鐵 綠 泥 石 & 4.08 & 9.685 & 0.82 \\
\hline M 28 & 䠃 & & 鐵致 & 鉸 & 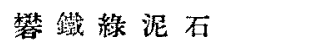 & 5.04 & 10.236 & 1.34 \\
\hline M 29 & 攀 & 鐵 & 緑 & 泥 石 & 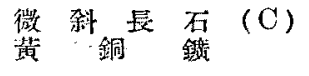 & 2.81 & 6.034 & 5.78 \\
\hline M 26 & 微 & 斜 & E & 石 (C) & 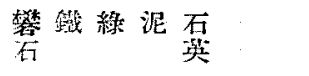 & 2.58 & 10.112 & 2.31 \\
\hline M 18 & 频 & 水 & 鉛 & 鑑 (D) & 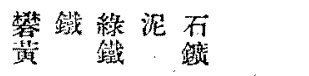 & 4.83 & 10.197 & 1,26 \\
\hline
\end{tabular}




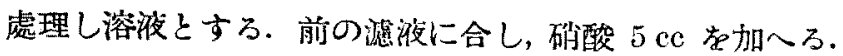
以後の測定方法は前報》と全く同樣であるから省略する.

ラドン計恒数

測定結果は第1表の如くである.
$K=29.70 \times 10^{12-} \mathrm{g} R a$ 每目盛/分

及び $27.13 \times 10^{-12} \mathrm{~g} R a$ 每目盛/分

测 定 結 果

\section{結果に對する考察}

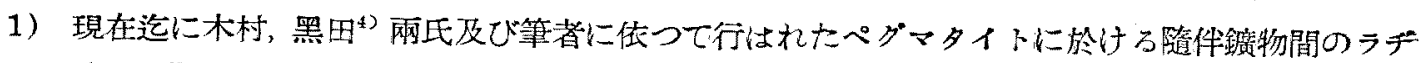

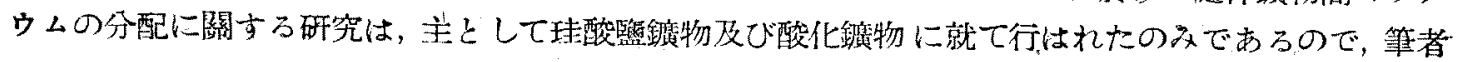

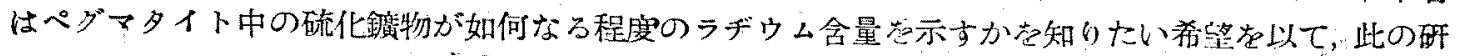

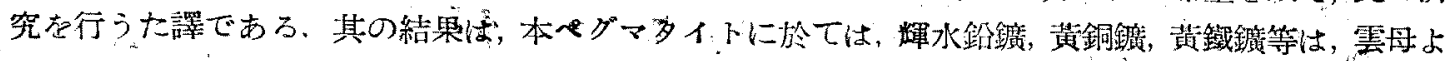
りは小さいが，長石よりは少しく大きいラヂウム含量芷示し，不英のそれよりは可成高い，然し之は 僅に一ヶ所の例であるので，果して他地方のペダマタイトに就てもかつる事の成立するや否やは今後 研究して見たいと思うてるる.

2）鑛物のラヂウム含量は，樊鐵綠泥石を最大に次の順序となる.

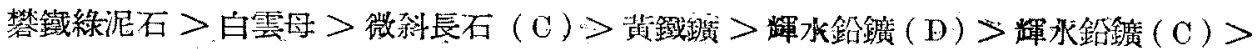

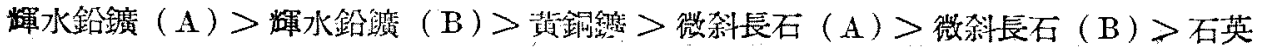

$(D)>$ 石英 $(B)>$ 石英 $(A)>$ 石英 $(\mathrm{C})$

3）同一鑛物に就き各く平均值を取れば第 2 表の如くなる.

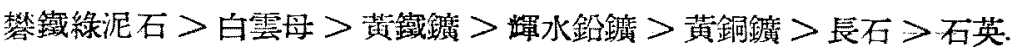

但し微科長石（C）は可成不純であり，綠色鑛物を多く含さので除外してある.

\begin{tabular}{|c|c|c|c|c|}
\hline 鐵 & “物 & 名 & 試料敖 & $\begin{array}{c}\text { ラヂウム命䎡 } \\
\left(10^{-12} \mathrm{~g} R a / g\right)\end{array}$ \\
\hline 薪 & 鐵綠 浑 & 石 & 1 & 5.78 \\
\hline 白 & 雲 & 柊 & 1 & 2.97 \\
\hline 黄 & 觛 & 籍 & 1 & 1.24 \\
\hline 莓 & 水 鉛 & 鏙 & 4 & 1.03 \\
\hline 黄 & 銅 & 鑑 & 1 & 0.82 \\
\hline & 斜 長 & 石 & 2 & 0.70 \\
\hline 石 & & 葓 & 4 & 0.12 \\
\hline
\end{tabular}

ム合量は大なる變動支示されない.

4）前報に見られた如き，鑛物の比重とラヂウム含量 との關係は今回は別に見られない.

5）各龲物のラヂウム含量が, 产狀とか隨伴鑛物の相: 違に依つて如何に變動するか存察すると, 次の諸點が 見られろ。

石英胍中の石英 (A)，(B)，(C)とペダマタイト中 の石英 (D) とはラヂウム含量にあまり差はないが, ペ グマタイト中の石英の方がや，含量が大きい，又輝水鉿

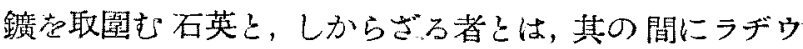
ム含量の變動が認められない，全䌡として石英のラヂゥ

微斜長石は（A），(B) の含量は殆ど相等しいが（C）は其の粎 4 倍の含量を元して居る. 其の理

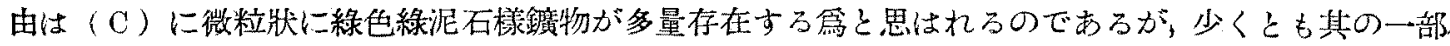
は琶らく礬鐵綠泥石と考へられれるので, 攀鐵綠泥石のラヂウム含量の高いのと比較教察すれば，當 然である。

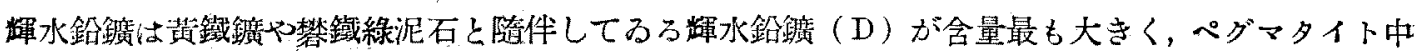
の者が最も小さいが，あまり著しい變動はない。

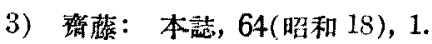

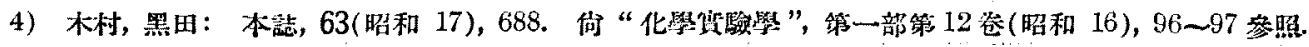


攀鐵綠泥石のラヂウム含量の大きい事は，注目に值するが，木野崎吉郎氏に依ればら)，此が長石，石

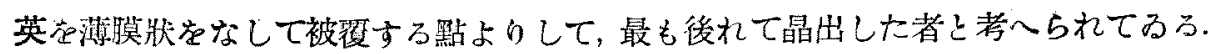

6）他地方产の鋠物とラデウム含量を比較すれば次の如くである.

石英は第 3 表の如く茨城縣山の尾のペグマタイトに産する者とほぶ等しく，現在迄に測定せられた 者の中ではラヂウム含量の大きい方に屬する.

\section{第 3 表 石英のラヂウム含量}

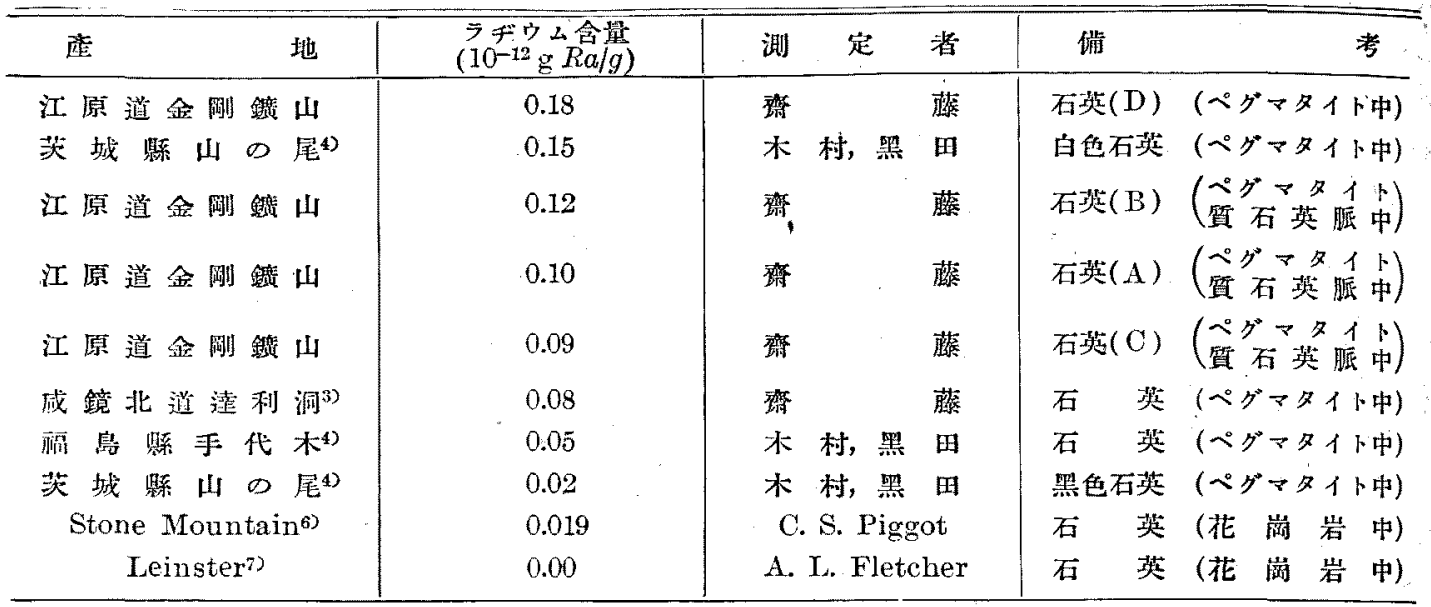

第 4 表長石のラヂウム舍量

\begin{tabular}{|c|c|c|c|c|c|}
\hline 虐 & $\begin{array}{c}\text { テデロム念舅 } \\
\left(10^{-12} \mathrm{~g} R a / g\right)\end{array}$ & 湘 & 定 & 者 & 借 \\
\hline Stone Mountain ${ }^{63}$ & 1.657 & \multirow{2}{*}{\multicolumn{3}{|c|}{$\begin{array}{l}\text { C. S. Piggot } \\
\text { C. S. Piggot }\end{array}$}} & 斜豦石（花 嵌 岩 中） \\
\hline Stone Mountain ${ }^{6)}$ & 1.129 & & & & 加里長石 (花 南 岩 中) \\
\hline 江原道金揃鑑山 & 0.72 & \multicolumn{2}{|c|}{ 登 } & 藤 & 微斜辰石(A)(ペダマタイト中) \\
\hline 江原道金测鑛山 & 0.67 & \multicolumn{2}{|c|}{ 蜜 } & 㭠 & 微斜卧石 (B)(ペグマタイト) \\
\hline Leinster $\bar{\imath}$ & 0.52 & \multicolumn{3}{|c|}{ A. L. Fletcher } & 長 石 (花 南 岩 中) \\
\hline 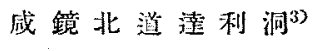 & 0.17 & 唯 & & 藤 & 加里長石(B)(ペグ マタイト中) \\
\hline 成箕北道潐利 洞 ${ }^{32}$ & 0.15 & 旖 & & 藤 & 加里長石 (A)(ペダマタ)ト中) \\
\hline 茨城縣山の尾 & 0.11 & 木 & 村, 㫮 & 田 & 斜長石（ぺグマタイト中） \\
\hline 茨城照山口尾筑 & 0.09 & 未 & 村, 黑 & 田 & 正長石（ぺク゚マタイト中） \\
\hline 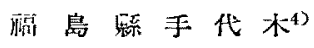 & 0.05 & 木 & 村, 黑 & 田 & 長 石（ペグマタイト中） \\
\hline
\end{tabular}

第 5 表白雲母のラヂウム含量

\begin{tabular}{|c|c|c|c|}
\hline 鹿 & $\begin{array}{l}\text { ラヂウム念量 } \\
\left(10^{-12} \mathrm{~g} R a / g\right)\end{array}$ & 湘＼cjkstart定 & 碏 \\
\hline Stone Mountain ${ }^{82}$ & 27.5 & C. S. Piggot & 白雲母（花南岩 中） \\
\hline North Jayss & 20.7 & C. S. Piggot & 白雲拝（花崗岩 中） \\
\hline Stone Mountain ${ }^{6} 2$ & 3.832 & C. S. Piggot & 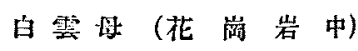 \\
\hline 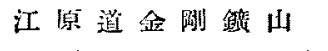 & 2.97 & 㱸藤 & 白雲坶（ペダマタイト中） \\
\hline 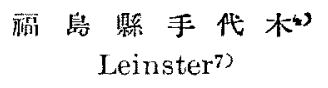 & $\begin{array}{l}1.79 \\
0.72\end{array}$ & $\begin{array}{l}\text { 木 村, 照 田 } \\
\text { A. L. Fletcher }\end{array}$ & $\begin{array}{l}\text { 白零母 (ペグ、タイト中) } \\
\text { 白雲母 (花 峝岩 中) }\end{array}$ \\
\hline 茨城綵山の尾 & 0.56 & 末 村, 黑 田 & 白雲舟 (ぺダマタイト中) \\
\hline
\end{tabular}

5) 木野崎氏の談話に依る.

6) C. S. Piggot: J. Am. Chem. Soc., 50(1928), 2910.

7) A. L. Fletcher: Phil. Mag. 6th Ser., 21(1911), 102.

8) C. S. Piggot: Am. J. Sci., 23(1932), 49. 
長石は第 4 表の如く微殺長石 (C) の值を除いても洋利洞產, 山の尾座, 手代木產に比すれば含量 一が可成大きく，外國産と比較するに Stone Mountain 產には及ばないが, Leinster 産よりは僅に大 きい。

白雲母は第5表の如く山の尾產，手代木產に僈つてろろが，外國產と比較するに Stone Mountain 座及び North Jay 産に劣り Leinster 花崗岩の白雲母に優つてるる.

硫化鑛物のラヂゥム含量は筆者の知れる限りでは，R. J. Strutt"9 の古い測定值が存するの及であ

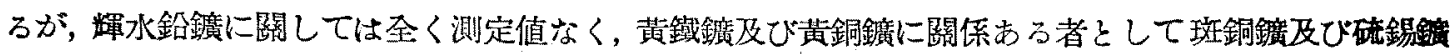
の测定值が有ろ. 此死表示すれば第 6 表の如くであり，Cornwall 產斑銅鑛のラヂゥム舍量は亟めて

第 6 表 硫化鏣物のラヂウム含量

\begin{tabular}{|c|c|c|c|c|c|c|c|}
\hline 箦 & \multicolumn{2}{|c|}{ 物 } & 名 & 座 & 測 & 定 & $\begin{array}{l}\text { ラデウム念量 } \\
\left(10^{-12} \mathrm{~g} R a / g\right)\end{array}$ \\
\hline 斑 & \multicolumn{2}{|c|}{ 铜 } & 鉵99) & Corṇwall & \multicolumn{2}{|c|}{ R. J. Strutt } & 10.4 \\
\hline 䕬 & \multicolumn{2}{|c|}{ 瀻 } & 鑑 & 江原道 金剛鑑 山 & 擢 & 藻 & 1.34 \\
\hline 歯 & 水 & 鉛 & 鉷 & 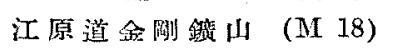 & 葴 & 藤 & 1.26 \\
\hline 数直 & 水 & 鉛 & 䤵 & 江原造金䦌䤵山 (M l6) & 旗 & 藤 & 1.04 \\
\hline 齳 & 水 & 鉛 & 錎 & 江原道金剧鑑山 (M 15) & 落 & 藤 & 0.94 \\
\hline 緟 & 水 & 鉛 & 鐶 & 江原道金测锤山（M $17 ）$ & 筬 & 藤 & 0.87 \\
\hline 黄 & \multicolumn{2}{|c|}{ 銅 } & 鑑 & 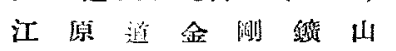 & 蘗 & 藤 & 0.82 \\
\hline 耀住 & \multicolumn{2}{|c|}{ 安 } & 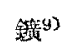 & New South Wales & \multicolumn{2}{|c|}{ R. J. Strutt } & 0.42 \\
\hline 閃 & 亞 & 鉛 & 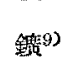 & $\begin{array}{l}\text { Minerva Mine, Wrexham, } \\
\text { Denbigh }\end{array}$ & \multicolumn{2}{|c|}{ R. J. Strutt } & 0.227 \\
\hline 硫 & \multicolumn{2}{|c|}{ 錫 } & 石 $^{9)}$ & Cornwall & \multicolumn{2}{|c|}{ R. J. Strutt } & 0.100 \\
\hline 方 & \multicolumn{2}{|c|}{ 鉛 } & 辕9) & Nenthead, Cumberland & & J. Strutt & 0.0291 \\
\hline
\end{tabular}

大きいが，他は本鑛山座の硫化鐄物に及ばない、硫化鑛物のラヂウム含量は未だあまり砫究されてを らぬ狀態であり，今後筆者は硫化鑛物に就て種々測定を䉆したいと考へてるる。

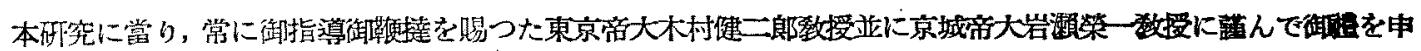

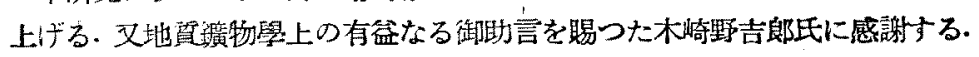

(京城帝國大學理工學部分析化学枚宝)

9) R. J. Strutt: Proc. Roy. Soc., A, 80(1908), 572. 